\title{
How to Satisfy the One Third Gender Rule in Kenya
}

\author{
Nyamu, Daniel Maringa* \\ Department of Mechanical Engineering; Technical University of Mombasa, \\ PO Box 90420-80100, Mombasa, Kenya
}

\begin{abstract}
Kenyan politics, public and private institutions, as well as family life today is largely male dominated. Many incidents in daily life reinforce male chauvinism. The constitution of Kenya, 2010, calls for not more than 2/3 gender representation in public institutions and in government appointments. This is an attempt to empower women to contest for public and political positions in parliament, Senate, MCA etc. This paper demonstrates the use of mathematical statistics to solve a social problem. Taking the case of Governor's seat, the use of IEBC boundaries gives 47 regions in Kenya. These are divided into three equal groups A, B and C by the method of picking lots. In doing so, random numbers can also be consulted. To legalize, these groups are gazetted, early and in good time, so that all Kenyans know which counties will produce women leaders in the general elections held in which year.
\end{abstract}

Keywords: constitution, mid-term, continuity, gender, two thirds, random number, MP, MCA, nomination, IEBC, DOI: $10.7176 /$ RHSS/9-8-04

Publication date: April $30^{\text {th }} 2019$

\section{Introduction}

The Kenyan woman, on a political and social standpoint, has made some progress but is not out of the woods yet. The Kenyan man is stronger than the Kenyan woman in muscle and brawn terms, on the average. Fewer girls than boys finish high school, fewer girls than boys enroll in Universities in virtually all programmes. In some Kenyan cultures, practices that encumber the progression of the woman are entrenched: FGM, early girl child betrothal, failure to enroll girl child in school, too much domestic chores at the expense of evening studies etc. The Kenyan woman finds contending with the Kenyan man a bit hard.

And yet, the Kenya Constitution (2010) called for not more than $2 / 3$ gender representation in public institutions and in government appointments. Parliament was to enact laws so that this requirement was implemented. Sadly, nine years down the road and two general elections later, (2013 and 2017), this has still not materialized.

Kenya, as a nation, needs to devise a method that will generate $1 / 3$ gender for elective and government appointment positions.

The Kenyan political landscape is divided into 47 regions hitherto known as districts but nowadays called counties. Each county, in a general election, will elect a senator and a governor. The question is this; how can one third of 47 elected governors/senators be female? At another level the nation of Kenya is divided into 290 constituencies, each electing an MP. Now, how can one third of 290 MP's be female?

Also, a constituency is divided into about 5 wards, each of which elects a member of county assembly, (MCA). Again the question; how to generate one third of all Kenyan MCA's to be female?

Among the poor solutions proposed is nomination, i.e. for example in the parliamentary election of 290 MP's, supposing 280 men and 10 women are elected. Then 280 is two-thirds, half of which is 140 . Therefore the number of women (10) needs to be boosted to 140 . And so 130 more women should be brought on board, by way of nomination: whereby the various political parties name extra female members in proportion to their numerical performance in the general election. This method comes with a high price tag: a house intended for 290 now must hold 290 plus 130 i.e. 420 . These extra members must have offices and salaries at the cost of the taxpayer. It is doubtful whether these nominated additional members add equal value to the system.

The constitution of Kenya, 2010, calls for not more than 2/3 gender representation in public institutions and in government appointments .(National Council for Law Reporting-2010). The electoral rules need to comply such that not more than two-thirds of the members of elective public bodies shall be of the same gender (The Constitution of Kenya, 2010).

The government has labored to implement this clause, making it look like an impossible problem. There has been much talk and hot air, generally unhelpful, and in the main driven by selfish and short sighted rhetoric.

\section{Literature Review}

\subsection{Midterm elections in the United States-The Inspiration}

In the United States, the president and vice president are elected every four years in indirect (electoral college) presidential elections. The legislative bodies of the US are the Senate (who serve six year terms) and House of Representatives ( 2 year terms). The Senate has $1 / 3$ of its members up for election every two years while the House 
has all its membership up for election every two years. Regarding elections to the United States Congress, the point of reference is the president's term. There are three classes of United States Senators; each election replaces one class, hence a "midterm election" appears as one-third through the term of one class and two-thirds through the other, while still midway the term of a president. While the Philippines and Liberia also conducts midterm elections, the winners of such elections take office in their respective legislative bodies that conduct such elections midway through the term of half of the other members; hence for the members who were not up for election, the incoming members take office midway through their terms.

Midterm elections in the United States refer to general elections in the United States that are held two years after the quadrennial (four-year) elections for the President of the United States (i.e. near the midpoint of the fouryear presidential term). Federal offices that are up for election during the midterms are members of the United States Congress, including all 435 seats in the United States House of Representatives, and the full terms for 33 or 34 of the 100 seats in the United States Senate.

Senators serve six-year, overlapping terms. One-third of all U.S. Senators are elected during each midterm and each Presidential election year. There are 100 U.S. Senators, two from each state. The method described above for electing the United States Senate ensures continuity and experience. At any time 1/3 of the Senators have four years' experience.

\subsection{The Kenyan conundrum}

In Kenya, it has been the case that after every parliamentary election, a majority of the members $(70 \%-75 \%)$ are voted out and new members voted in. These new members often lack the knowledge and decorum for parliamentary procedures and, being the majority, are often able to corrupt the statutes. The Kenyan parliament lacks continuity indeed.

The authors of the Kenya Constitution wanted greater participation from women to the tune of $1 / 3$. Nine years down the road and two general elections later, (2013 and 2017), this has still not materialized.

The main reasons are male chauvinism/avarice, and the presentation of wrong and or false arguments, some quite disingenuous. A male versus female political contest in Kenya is usually not a fair fight.

\section{Methodology}

\subsection{Dividing the Counties into three groups $A, B$ and $C$}

Inspired by the US method of maintaining continuity in the senate, the author has devised a purely statistical method, buttressed by some legal provisions, to solve the problem. The application of this method will generate one-third opposite gender at no extra cost.

The statistical method the author describes here is applicable to either the Kenyan senate or governorship elections, since these electoral regions share the same boundaries. There are 47 regions, serialized by the electoral commission as $001,002,003 \ldots \ldots \ldots \ldots . . .045,046$ and 047 . The 47 counties are divided into three groups: Group A with 16 members; Group B with 16 members and Group C with 15 members. In the most immediate forthcoming general election, (2022), Group A counties should elect women governor's exclusive. This will be achieved by a legal decree, published in the Kenya gazette, early and in good time, stating that governor contestants in Group A counties in 2022 must be women. Sponsoring parties like Jubilee, Wiper, KANU and ODM should comply, or have their 'male' candidate rejected by the electoral body (IEBC). Meanwhile, Group B and C in 2022 will be open to male and female contestants: it is expected that male contestants will easily defeat female contestants.

In the subsequent general election, (2027), it would be the turn of Group B counties to elect, exclusively, female governors. As in the paragraph above, this is achieved by a legal decree, published in the Kenya gazette, early and in good time, stating that governor contestants in Group B counties in 2027 must be women. Sponsoring parties like Jubilee, Wiper, KANU and ODM should comply, or have their 'male' candidate rejected by the electoral body (IEBC). In 2027, Group A and C counties, in the governor's contest, will be open to male contestants; it is expected that these male contestants will easily defeat the female contestants, including the Group A female incumbents.

In the next general election (2032), it will be the turn of Group C counties to produce female governor's. As in the paragraph above, this is achieved by a legal decree, published in the Kenya gazette, early and in good time, stating that governor contestants in Group C counties in 2032 must be women. Sponsoring parties like Jubilee, Wiper, KANU and ODM should comply, or have their 'male' candidate rejected by the electoral body (IEBC). In 2032, Group A and B counties, in the governor's contest, will be open to male contestants; it is expected that these male contestants will easily defeat female contestants.

In 2037, it will then be the turn for Group A counties to elect female Governor's and the cycle is repeated. The last three paragraphs have labored to set forth a legal and executive framework of producing 47 governor's in a general election, one third of whom are female. 


\subsection{Picking lots to allocate counties to a group-random numbers}

To allocate the counties to Groups A, B and C, lets refer to Table 1. First, the county numbers 1- 47 are serialized (column 1). Any of several methods of selection can follow, as discussed below.

\subsubsection{The deck of cards}

Pick a newly purchased deck of cards. It has a total of 52 cards. Take 47 of them, and mark them on the front side with the serial numbers 001- 047. Turn them upside down and shuffle them. Representatives of the different counties can now pick a card each. Card numbers 001- 016 will be picked by Group A counties; Card numbers 017 -032 will be picked by Group B counties, while card numbers $033-047$ will be Group C counties. The result is the number $\mathrm{R}-\mathrm{n} 47$ for each county (Table 2 )

3.2.2 The paper balls

From a plain sheet of paper cut 47 square pieces of side 2 inches. Mark each of these pieces of paper with the serial numbers $001-047$. Fold and roll each piece of paper into a ball to hide the digital marks. The paper balls are placed in an empty drum, which is then closed and rotated to shuffle. County representatives are then invited to pick a ball each. The result is as in the paragraph above.

3.2.3 Random numbers

From mathematical tables pick random numbers. In this case, and on account that the population (counties) are only 47, the author picked a two digit random number per county. The result is the random number R (column 3 in Table 1) (SMP Advanced Tables 1987).

Column 2 is obtained by performing the arithmetic $(\mathrm{R}-\mathrm{N} 47)$ where $\mathrm{N}$ is the integer 0,1 or 2 and the result should be a positive number. In S/No. 1, $34-0 \times 47=34$. In S/No.2, $91-1 \times 47=44$. In S/No. 27 and 42, $98-2 \times 47=$ 4. In S/No. 27, we have drawn 4 for the first time whereas in S/No. 42 the digit 4 is drawn a second time. The digit 19 is drawn four times, in S/No. 11, 13, 24 and 36. We realize that Group A has been claimed on more than 16 occasions whereas Group $\mathrm{C}$ is being claimed less than 15 times. In allocating, counties 31, 12, 15, 27, 23,17, 4, 10 and 30 easily fall into Group A. County number 6, having drawn slot number 7, occupied by county number 4 , will have to await a subsequent allocation. That is how county number 6 ended up in Group $\mathrm{C}$ after a second allocation picked counties 37, 22, 21, 47, 29, 42 and 34 for group A. By similar happenstance B and C members are revealed.

By this expedient, we shall get at least $1 / 3$ women leaders without having to spend extra money.

\section{Results/Benefits}

Table 1 shows each of the 47 counties segmented into either of groups A, B, or C. Column one is serial number or county number, column 3 is the random number, and column 2 is $R-n 47$. Column 4 is interim group first allocation, generally confirmed by default, but can be denied by column 5 . Table 2 is the final summary of the maneuvers in Table1. Table 2 is also the typical result of picking from the deck of cards or rolled balls. A rhetorical argument advanced by male political mischief makers is that their right to vie for a political position has been abridged. The reply is simple. Let any such person contest in those counties open to all. If he is worth his salt, he should win 'there'.

The benefits of this scheme is that a method has been formulated that generates $1 / 3$ gender positions. If done transparently with open debate and in good time, the fairness and justice of it will be clear to all. The fact that the method does not require extra funding is also a good point.

\section{Conclusion/Recommendations}

The method proposed for achieving 1/3 gender balance on public institutions and government appointments in Kenya, if implemented as proposed, would solve the problem neatly and at no extra cost. The method comes out as fair and just. For general acceptance, the method could be discussed in public forums before implementing.

\section{References}

National Council for Law Reporting. (2010). The Constitution of Kenya. National Council for Law Reporting with the Authority of the Attorney General. (www.kenyalaw.org)

The School Mathematics Project (1987). SMP Advanced Tables. (Third Edition) Press Syndicate of the University of Cambridge. 
ISSN 2224-5766 (Paper) ISSN 2225-0484 (Online) DOI: 10.7176/RHSS

Vol.9, No.8, 2019

\begin{tabular}{|c|c|c|c|c|}
\hline S/No. (counties) & (R-n47) & $\mathrm{R}$ (random no.) & GROUP & override \\
\hline 1 & $34 *$ & 34 & $\mathrm{c}$ & \\
\hline 2 & $44^{*}$ & 91 & $\mathrm{c}$ & \\
\hline 3 & $25 *$ & 25 & $\mathrm{~b}$ & \\
\hline 4 & $07-01^{*}$ & 54 & $\mathrm{a}$ & \\
\hline 5 & $33^{*}$ & 33 & $\mathrm{c}$ & \\
\hline 6 & $07-02$ & 07 & $\mathrm{a}$ & $\mathrm{c}$ \\
\hline 7 & $18 *-01$ & 65 & $\mathrm{~b}$ & \\
\hline 8 & $32 *$ & 79 & $\mathrm{~b}$ & \\
\hline 9 & $24-01 *$ & 24 & $\mathrm{~b}$ & \\
\hline 10 & $14 *$ & 61 & $\mathrm{a}$ & \\
\hline 11 & $19-01 *$ & 19 & $\mathrm{~b}$ & \\
\hline 12 & $02 *$ & 02 & $\mathrm{a}$ & \\
\hline 13 & $19-02$ & 66 & $\mathrm{~b}$ & \\
\hline 14 & $20-01^{*}$ & 67 & $\mathrm{~b}$ & \\
\hline 15 & 03-01* & 97 & $\mathrm{a}$ & \\
\hline 16 & $30 *$ & 30 & $\mathrm{~b}$ & \\
\hline 17 & $06-01 *$ & 06 & $\mathrm{a}$ & \\
\hline 18 & $26^{*}$ & 73 & $\mathrm{~b}$ & \\
\hline 19 & $46^{*}$ & 46 & $\mathrm{c}$ & \\
\hline 20 & $18-02$ & 65 & $\mathrm{~b}$ & \\
\hline 21 & $07-03$ & 07 & $\mathrm{a}$ & \\
\hline 22 & 03-02 & 03 & $\mathrm{a}$ & \\
\hline 23 & $05-01^{*}$ & 05 & $\mathrm{a}$ & \\
\hline 24 & 19-03 & 66 & $\mathrm{~b}$ & \\
\hline 25 & $41^{*}$ & 88 & $\mathrm{c}$ & \\
\hline 26 & $40 *-01$ & 87 & $\mathrm{c}$ & \\
\hline 27 & $04 *-01$ & 98 & $\mathrm{a}$ & \\
\hline 28 & $40-02 *$ & 87 & $\mathrm{c}$ & \\
\hline 29 & $07-04 *$ & 07 & $\mathrm{a}$ & \\
\hline 30 & $15^{*}$ & 62 & $\mathrm{a}$ & \\
\hline 31 & $01 *$ & 48 & $\mathrm{a}$ & \\
\hline 32 & $47 *$ & 94 & $\mathrm{c}$ & \\
\hline 33 & $20-02$ & 67 & $\mathrm{~b}$ & \\
\hline 34 & $05-02 *$ & 52 & $\mathrm{a}$ & \\
\hline 35 & $24-02$ & 24 & $\mathrm{~b}$ & \\
\hline 36 & 19-04 & 66 & $\mathrm{~b}$ & \\
\hline 37 & $07-05^{*}$ & 54 & $\mathrm{a}$ & \\
\hline 38 & 39-01* & 39 & $\mathrm{c}$ & \\
\hline 39 & $22 *$ & 22 & $\mathrm{~b}$ & \\
\hline 40 & $27 *$ & 74 & $\mathrm{~b}$ & \\
\hline 41 & 06-02 & 00 & $\mathrm{a}$ & $\mathrm{c}$ \\
\hline 42 & $4-02 *$ & 98 & $\mathrm{a}$ & \\
\hline 43 & $20-03$ & 67 & $\mathrm{~b}$ & \\
\hline 44 & $36^{*}$ & 36 & $\mathrm{c}$ & \\
\hline 45 & $39-02 *$ & 86 & $\mathrm{c}$ & \\
\hline 46 & $28 *$ & 28 & $\mathrm{~b}$ & \\
\hline 47 & 06-03* & 53 & $\mathrm{a}$ & \\
\hline
\end{tabular}

Table 1:The random number is converted into a group $(\mathrm{a}, \mathrm{b}$ or $\mathrm{c})$ 


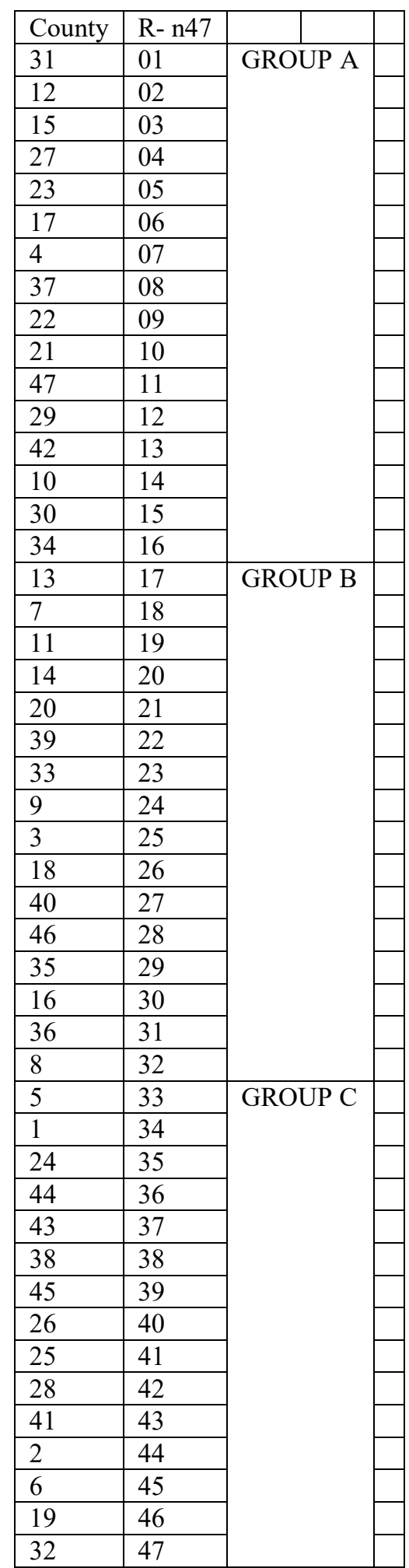

Table 2: Final summary of Table 1. 